\title{
IDENTIFYING NATIVE AND EXOTIC PREDATORS OF GROUND-NESTING SONGBIRDS IN SUBANTARCTIC FORESTS IN SOUTHERN CHILE
}

\author{
IDENTIFICANDO LOS DEPREDADORES NATIVOS Y EXÓTICOS SOBRE LOS PASSERIFORMES \\ QUE NIDIFICAN EN EL SUELO DE LOS BOSQUES SUBANTÁRTICOS EN EL SUR DE CHILE
}

\author{
Brett M. Maley ${ }^{1,2}$, Christopher B. Anderson ${ }^{2,3,4}$, Kirk Stodola ${ }^{1} \&$ Amy D. Rosemond ${ }^{5}$
}

\section{RESUMEN}

Las aves Passeriformes constituyen el grupo más diverso y abundante de vertebrados en el archipiélago austral de Sudamérica. Sin embargo, se desconocen varios aspectos claves de su ecología, tales como el éxito de nidificación y sus depredadores. El visón americano (Neovison vison) fue introducido a Tierra del Fuego en la década de 1940 e invadió la Reserva de la Biosfera Cabo de Hornos, al sur del Canal Beagle en 2001. Como nuevo depredador tope, el visón invasor puede tener impactos significativos sobre las especies de aves nativas, incluyendo algunos Passeriformes del bosque que nidifican al nivel del suelo. Para determinar la identidad y el efecto de los depredadores de nidos en el suelo, condujimos un experimento con nidos artificiales y determinamos el impacto de los depredadores en las tasas de supervivencia diarias de nidos en tres tipos de hábitats diferentes (matorrales antropogénicos, pastizales de castoreras y bosques). El 65\% de los nidos fueron depredados (40\% debido al chercán nativo [Troglodytes musculus] y $25 \%$ debido al visón exótico). Sin embargo, se encontró que el visón fue la causa del 53\% del fracaso de los nidos en el matorral antropogénico. Estos resultados demuestran que tanto los depredadores nativos como los exóticos afectan el éxito de nidificación de la avifauna del bosque subantártico, pero el efecto de un depredador tope invasor, como el visón, constituye una nueva amenaza que podría afectar el éxito de nidificación y la sobrevivencia de los adultos.

Palabras clave: nidos artificiales, Passeriformes, Tierra del Fuego, visón americano.

1 Warnell School of Forestry and Natural Resources, University of Georgia, Athens, Georgia, USA.

2 Sub-Antarctic Biocultural Conservation Program, Universidad de Magallanes, Punta Arenas, Chile \& University of North Texas, Denton, Texas, USA.

3 Omora Ethnobotanical Park, Universidad de Magallanes, Puerto Williams, Chile \& Institute of Ecology \& Biodiversity, Santiago, Chile.

4 Corresponding author. christopher.anderson@umag.cl.

5 Odum School of Ecology, University of Georgia, Athens, Georgia, USA. 


\section{ABSTRACT}

Birds constitute the most diverse and abundant group of vertebrates in the austral archipelago of southern South America; yet key aspects of their ecology such as nesting success and predators are little known. The American mink (Neovison vison) was introduced to Tierra del Fuego in the 1940s and expanded its range south of the Beagle Channel into the Cape Horn Biosphere Reserve by 2001. As a new top predator, the invasive mink may have significant impacts on naïve avian species, including some forest Passeriformes that nest on the ground. To determine the identity and effect of ground nest predators, we conducted an artificial nest experiment and assessed the impact of predators on daily survival rates of artificial nests in three different habitat types (anthropogenic shrublands, beaver meadows, and forests). We found that $65 \%$ of nests were depredated (40\% due to native Southern House Wrens [Troglodytes musculus] and 25\% from mink). However, we discovered that mink were the cause of 53\% of the nest failures in the anthropogenic shrubland. These findings demonstrated that both native and exotic predators affect nesting success of subantarctic forest avifauna, but the influence of an invasive top predator, the mink, constitutes a new threat that will likely affect both nesting success and parental survival.

Key words: American mink, artificial nest, ground nesting songbirds, Tierra del Fuego

\section{INTRODUCTION}

While humans have introduced plant and animal species both purposefully and accidentally for millennia, the rate and impacts associated with modern invasive exotic species have become a major conservation concern (Cohen \& Carlton 1998, Levin \& D'Antonio 2003). Consequently, invasive exotic species are recognized as a global threat to biodiversity (Vitousek et al. 1997, Mack et al. 2000), even in otherwise remote and pristine wilderness areas such as the Cape Horn Biosphere Reserve, Chile (Anderson et al. 2006). Islands are particularly vulnerable to introduced predators, as isolated native taxa often evolved in the absence of terrestrial carnivores and can be "naïve" to protecting themselves from depredation (Roeman et al. 2002, Courchamp et al. 2003). Such effects of introduced predators are even more acute for insular bird communities, which account for $90 \%$ of the 100 birds that have gone extinct since 1600 (Bibby 1994).

This study was conducted in the Cape Horn Biosphere Reserve (CHBR) of southern Chile, specifically on Navarino Island. We examined the consequences of mink invasion, compared to potential native nest predators, on the avian community in the sub-Antarctic archipelago of southern Chile. This insular group includes the islands south of the Beagle channel to Cape Horn. In the 1940s, various government programs in both Argentina and Chile introduced exotic furbearers to Tierra del Fuego Island, including the establishment of mink (Neovison vison Schreber 1777) farms that eventually led to the naturalization of introduced populations of this invasive predator on Tierra del Fuego Island. The first confirmed mink specimen found in the CHBR was Navarino Island in 2001 (Rozzi \& Sherriffs 2003). Since then, the mink's distribution has expanded to include Hoste Island (Anderson et al. 2006).

Conservation managers have been particularly concerned about the effect of mink on the avifauna of the islands in the $\mathrm{CHBR}$, given their relative lack of native terrestrial vertebrate predators and the fact that numerous species of terrestrial and marine birds nest on the ground in this archipelago. It is known, for example, that the diet of the American mink in the CHBR includes rodents with important contributions from birds and fish, as well (Schuttler et al. 2008, Ibarra et al. 2009). Particularly in summer, birds significantly increase their percentage in the mink's diet with Passeriformes constituting the principal contribution (Schuttler et al. 2008). We also know that as a group, birds are the most abundant and speciose terrestrial vertebrates in the archipelago (Venegas \& Siefeld 1999). Therefore, the avifauna of the CHBR is expected to be uniquely important not only to the area's overall biodiversity, but also in providing ecosystem services, such as the dispersal of seeds and pollination. Yet, to date, little information is available about the potential 
impact of either native or exotic predators on the forest avifauna of the CHBR.

Here, we explored the consequences of mink invasion on ground-nesting Passeriformes. To better understand the ecological role played by the invasive American mink in sub-Antarctic forests, we carried out an artificial nest study in the Omora Ethnobotanical Park (OEP: 55응 S) to measure the relative risk of depredation by mink and other potential predators in the three dominant habitat types of the north coast of Navarino Island: anthropic shrubland, beaver meadows, and forested habitat. We hypothesized that introduced mink depredation on artificial nests would be most important in habitats with greater disturbance, which have been shown to decrease safe nesting sites (Gates \& Gysel 1978, Willson et al. 2001).

\section{METHODS}

We characterized the community of potential predators and also bird species that occupy the subAntarctic forest, using the OEP's database of over 6,000 captures of principally forest Passeriformes during a long-term mist netting program (period: 2000-2007) (Anderson et al. 2002). Utilizing this database, we determined: a) the total assemblage of forest avifauna and $b$ ) the relative frequency of the principal forest songbird species in the CHBR that represented $>1 \%$ of captures. Opportunistic mist netting surveys conducted at high elevation sites (i.e. above tree line) were excluded from this analysis. In addition, we used data from previous surveys of the archipelago-wide vertebrate fauna (Anderson et al. 2006) and a literature review to determine potential nest predators. Nesting location and type of nest were determined from personal observation and a decade of field notes and experience, accumulated by the Omora Sub-Antarctic Bird Observatory (2000 to present).

\section{Study sites}

The study took place in the OEP on the north shore of Navarino Island in the CHBR, Chile (55ㅇ) The OEP is one of three long-term socio-ecological research (LTSER) sites coordinated by the Institute of Ecology and Biodiversity (www.ieb-chile.cl/ltser). The eco-region, known as the Magellanic Sub-Antarctic
Forest Biome, is considered one of the world's most pristine remaining wilderness areas (Mittermeier et al. 2003). However, while the archipelago has a low degree of habitat fragmentation and a sparse human population, it is paradoxically replete with exotic species, including the American mink, North American beavers (Castor canadensis Kuhl 1820), muskrats (Ondatra zibethicus Linnaeus 1766), feral dogs, cats, and livestock (Anderson et al. 2006).

\section{Artificial nest experiment}

To determine nest predator identity and the relationship of nest failure with habitat type, we used an artificial nest experiment with plasticine eggs. Two sites per habitat type were used to distribute artificial nests ( $n=60$ ), which were made of $100 \%$ dehydrated and sterilized coconut fiber (approx.120 mm diameter). Eggs were made using a mix of white and blue colored plasticine clay (approx. $30 \mathrm{~mm}$ long). Both size and color mimicked natural Austral Thrush (Turdus falcklandii Quoy \& Gaimard 1824) nests and eggs. To standardize clutch size, three eggs were placed in each nest, and nests were placed at locations that simulated natural nesting sites for ground-nesting songbirds found at the OEP, usually under downed logs or at the base of shrubs. Nests were checked every three days from 3 to 30 October 2005. Nitrile gloves were worn when handling nests and eggs, and they were considered depredated if they had scratch marks, were missing, had puncture holes, or were torn apart. If a nest failed between subsequent checks, we marked the failure date as the midpoint between these checks. The identity of nest predators was determined using a reference collection of potential predator teeth marks on eggs. A preserved specimen of mink was obtained from the Martin Gusinde Anthropological Museum. Various bird specimens, including wrens and rayaditos, were obtained during the course of the Omora Park's monthly bird banding project. A simultaneous study of native mice that were trapped in the OEP with Sherman traps allowed us to obtain local native mice species for creating their teeth prints on reference eggs.

We calculated the probability of daily nest mortality due to mink using the Mayfield logistic regression (Hazler 2004). For nests that were depredated by other predators, we only included 
observation days prior to the midpoint between the last active nest check and the date we found the nest depredated. Our model relating depredation rate to habitat was analogous to a completely randomized nested design, and we used the type 3 analysis in Proc LOGISTIC (SAS 2006), which is based on the Wald test, to determine if a difference exists among habitat type. Finally, we interpreted nest depredation rate among sites using 95\% confidence intervals (Gerrard et al. 1998, Johnson 1999).

\section{RESULTS}

A total of 20 forest bird species were recorded from 2000 to 2007 in the OEP mist netting program, most of which were of Passeriformes (85\%) with the orders Falconiformes, Piciformes and Strigyformes having only one species each (Table 1). Of these 20 species recorded, 40\% were cavity nesters, 55\% nested in bushes and 10\% were frequently found to be ground nesters in the CHBR (the Austral Negrito - Lessonia rufa [Gmelin 1789], and the Austral Thrush - Turdus falcklandii) (Table 1). The Austral Negrito, however, is a species common in grasslands, and the Austral Thrush was the only common ground nesting forest taxon. Among the 20 recorded species in mist nets, 9 made up more than $1 \%$ of net captures (Fig. 1).

The exotic predator assemblage in the $\mathrm{CHBR}$ included feral domestic animals, such as dogs, cats and pigs, as well as the introduced mink (Table 2). Potential native nest predators were several mice and raptors, such as the Chimango Caracara (Milvago chimango Vieillot 1816). On Hoste and Tierra del Fuego Islands, the native Fuegian red fox (Pseudalopex culpaeus lycoides Molina 1782) is also present, and the introduced grey fox (Pseudalopex griseus Gray 1837) is found only on Tierra del Fuego Island.

Artificial nests were depredated by only two predators, the American mink and the Southern

Table 1. Bird species captured during the 2000-2007 mist netting program at the Omora Park, indicating their nesting mode.

\begin{tabular}{|c|c|c|c|}
\hline Order family & Genus and species & $\begin{array}{c}\text { Relative } \\
\text { Abundance (\%) }\end{array}$ & Nesting mode $e^{¥}$ \\
\hline \multicolumn{4}{|l|}{ Falconiformes } \\
\hline Falconidae & Milvago chimango* & 0.04 & Large nests in tree canopy \\
\hline \multicolumn{4}{|l|}{ Piciformes } \\
\hline Picidae & Campephilus magellanicus* & 0.06 & Cavity nest \\
\hline \multicolumn{4}{|l|}{ Strigyformes } \\
\hline Strygidae & Glaucidium nanum* & 0.01 & Cavity nest \\
\hline \multicolumn{4}{|l|}{ Passeriformes } \\
\hline Emberizidae & Zonotrichia capensis & 5.2 & Open cup nest in bushes and trees \\
\hline Emberizidae & Phrygilus patagonicus & 41.0 & Open cup nest in bushes and trees \\
\hline Emberizidae & Carduelis barbata & 6.6 & Open cup nest in bushes and trees \\
\hline Emberizidae & Cureus cureus & 0.03 & Open cup nest in bushes and trees \\
\hline Furnariidae & Pygarrihicus albogularis & 0.7 & Cavity nest \\
\hline Furnariidae & Cinclodes fuscus* & 0.07 & Cavity and open cup nest in bushes \\
\hline Furnariidae & Cinclodes patagonicus* & 0.1 & Cavity and open cup nest in bushes \\
\hline Hirundinidae & Tachycineta meyeni & 1.2 & Cavity nest \\
\hline Tyranidae & Anairetes parulus & 1.5 & Open cup nest in bushes and trees \\
\hline Tyranidae & Lessonia rufa* & 0.01 & Ground nester in grasslands \\
\hline Tyranidae & Xolmis pyrope & 0.6 & Open cup nest in bushes and trees \\
\hline Tyranidae & Elaenia albiceps & 13.2 & Open cup nest in bushes and trees \\
\hline Tyranidae & Aphrastura spinicauda & 19.8 & Cavity nest \\
\hline Tyranidae & Colorhamphus parvirostris & 0.04 & Open cup nest in bushes and trees \\
\hline Trochilidae & Sephanoides sephaniodes & 0.4 & Open cup nest in bushes and trees \\
\hline Troglodytidae & Troglodytes musculus & 7.6 & Cavity nest \\
\hline Turdidae & Turdus falcklandii & 0.1 & Open cup nest on ground in CHBR \\
\hline
\end{tabular}

* Not a target species of mist netting.

¥ Nesting mode was determined based on personal observations and more than a decade of field experience at the Omora SubAntarctic Bird Observatory. 


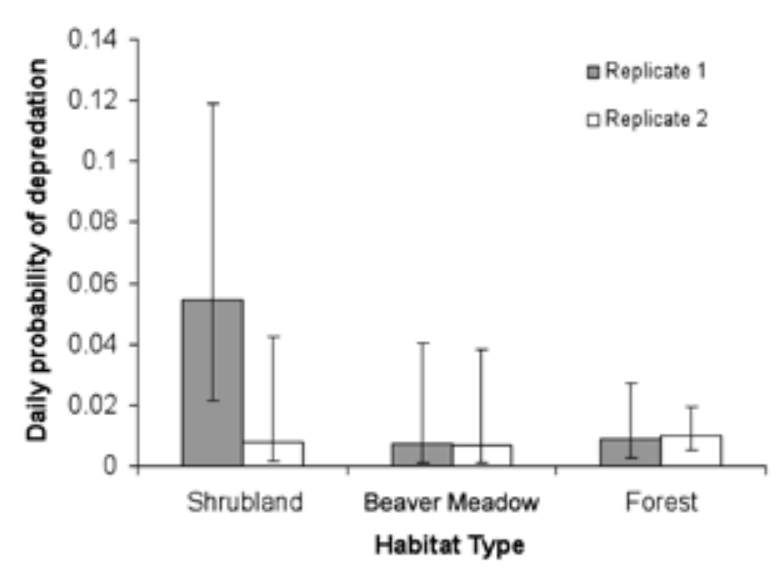

Fig. 1. Mean probability of daily nest failure due to mink, along with 95\% confidence intervals on each site in the three different habitat types: anthropogenic shrublands, beaver meadows and forests.

House Wren (Troglodytes musculus Naumann 1823). Wrens were the most common cause of nest failure for artificial nests (24\%), but mink depredated 53\% of nests in the anthropogenic shrublands that were affected mainly from one site that was located on the coast (Table 3). We found no statistical difference between habitat types in depredation rate due to mink $\left(\chi^{2}=2.55\right.$, d.f. $\left.=2, p=0.28\right)$. Depredation rates were very similar for 5 of the 6 sites, but were remarkably higher at one site in the shrubland habitat near the coast (Fig. 2).

\section{DISCUSSION}

Despite their methodological problems (Faaborg 2003), we believe that artificial nest experiments in this case provided us with a useful tool to evaluate the relative risk of nest predation (Willson et al. 2001). Since real nests were difficult to find in sufficient quantity for statistical analyses and natural nests are also usually not distributed across habitats at densities that satisfy an experimental methodology, this artificial nest experiment allowed us to evaluate depredation as influenced by ecological factors such as habitat type (Faaborg 2003). Although the artificial nest methodology may over- or underestimate actual failure rates, in this case it allowed us to determine overall trends of nest depredation for ground-nesting songbirds in the CHBR. Artificial nests also allowed us to discover the identity of potential predators of ground-nesting songbirds in sub-Antarctic forests.

Table 2. Potential nest predators in the Cape Horn Biosphere Reserve, indicating their distribution in the archipelago and their status as native or exotic.

\begin{tabular}{|c|c|c|c|c|}
\hline Scientific names & Common name & Status & Island & Source \\
\hline Sus scrofa & Feral pig & Exotic & Navarino, Hoste, Gordon & 1 \\
\hline Canis lupus familiaris & Feral dog & Exotic & TDF, Navarino, Hoste, Horn & 1 \\
\hline Felis domesticus & Feral cat & Exotic & Navarino, Horn & 1 \\
\hline Neovison vison & American mink & Exotic & TDF, Navarino, Hoste & 1 \\
\hline Abrothrix xanthorhinus & Yellow-nosed mouse & Native & TDF, Navarino, Hoste & $1,2,5$ \\
\hline Akodon hershkovitzi & Cape Horn mouse & Native & Herschel & 1 \\
\hline Euneomys chinchilloides & Fuegian chinchilla mouse & Native & TDF, Wollaston, Hermite, Hoste & 1 \\
\hline Oligoryzomys longicaudatus & Long-tailed mouse & Native & TDF, Wollaston, Hermite, Hoste & $1,2,4,5,6$ \\
\hline Pseudalopex culpaeus lycoides & Fuegian red fox & Native & TDF, Hoste & 1,3 \\
\hline Pseudolopex griseus & Grey fox & Exotic & TDF & 1 \\
\hline Milvago chimango & Chimango caracara & Native & Throughout & 7 \\
\hline
\end{tabular}

1. Anderson et al. 2006, 2. Cabrera 1961, 3. Olrog 1950, 4. Reise and Venegas 1997, 5. Sielfeld 1977, 6. Thomas 1916, 7. Venegas 1999

Table 3. Identity and percentage of predators that caused nest failures per habitat type.

Percentages are shown for each habitat type and for the total of all nests (last row).

\begin{tabular}{lccc}
\hline Habitat & \% Mink & \% Wren & \% Total \\
\hline Anthropogenic shrubland & 53 & 40 & 93 \\
Beaver meadow & 13 & 60 & 73 \\
Forest & 17 & 30 & 47 \\
\hline Total nests depredated & 15 & 24 & 39 \\
\hline
\end{tabular}


The mink was the cause of almost all nest depredations in one anthropogenic shrubland habitat. Mink are believed to be more common along the coast (Schuettler et al. 2009), but over time have the ability to move throughout the island if left unchecked. More studies should be done to determine mink densities and distribution on the island. At the same time, our discovery of wren nest predation was unexpected, but not without precedent in the literature. It is unknown at this point whether the depredation observed here was an artifact of the artificial nest methodology or a meaningful ecological phenomenon in our study system. However, similar intra-specific competition by wrens has been reported in North America (Simons \& Simons 1990), and this behavior may be a common feature of the wren family (Picman 1988). Our data provide further evidence that this is a general behavior and was an unexpected discovery regarding species interactions in sub-Antarctic forests. Nonetheless, our results probably overestimate the effects of wrens on real nests with parental defense, while on the other hand the effects of mink are likely greater in reality, since they are also capable of consuming the incubating parent.

If the mink continues to expand its range in the austral archipelago, the native forest birds that have evolved ground-nesting behavior will be adversely affected. However, it is unknown if these same species may develop defensive strategies in the short- to medium-term, such as moving their nests to trees. On the other hand, species such as coastal and wetland shorebirds do not have such an option. As the most abundant vertebrates in the archipelago, the birds of the CHBR are also expected to carry out important ecological functions, such as seed dispersal, pollination, and controlling insect populations, as well as providing an increasingly important resource for ecotourism in the area. To confront this potential conservation problem, the government of the Magallanes and Chilean Antarctic Region recently financed an invasive species control program. However, to date, no published information has existed on the effects of mink to forest avifauna to inform the decision-making of authorities and managers regarding this component of sub-Antarctic biodiversity.

We know that invasive predators have caused the extinction of native bird populations on other insular systems (Lockwood et al. 2007), and it is evident from this study that the exotic American mink have the capability of negatively impact native songbird bird populations in the Cape Horn Archipelago. Surprisingly, while native raptors and mice were also expected to be potential nest predators in this study area, we did not find any evidence of their effect on ground-nesting songbirds. In addition, the lack of a strong habitat effect on mink depredation of nests indicates that this species is widely distributed and has the capacity to influence birds nesting in a variety of habitats. Also, the unexpected discovery of wren depredation of nests in the austral archipelago serves to highlight the lack of basic information on the ecology of birds in sub-Antarctic forests, a gap in information that is systematically being addressed by the Omora Sub-Antarctic Bird Observatory's long-term avian research program.

\section{ACKNOWLEDGEMENTS}

Thanks to the Rosemond Lab group, B. Cooper and the Cooper Lab, as well as R. Rozzi and F. Massardo for making this research possible. B. Maley conducted this research while an exchange student facilitated through a UGA-UMAG memorandum of understanding. Bird banding research associated with the Omora database has been conducted under the permit of R. Rozzi (DEPROREN Permit N²641). A. Valenzuela provided valuable editorial comments. A. Trice, W. Collier and C. Morano provided assistance in the field. This publication is part of the long-term ecological investigations of the Cape Horn Biosphere Reserve (www.omora.org, www.umag.cl/williams, www.ieb-chile.cl/ltser), supported by ICM P05-002 and PFB-23.

\section{LITERATURE CITED}

Anderson, C.B., R. Rozzi, J.C. Torres-Mura, S.M. McGehee, M.F. Sherriffs, E. Schuettler \& A.D. Rosemond 2006. Exotic vertebrate fauna in the remote and pristine sub-Antarctic Cape Horn Archipelago region of Chile. Biodiversity and Conservation 10:3295-3313.

Bibby, C.J. 1994. Recent past and future extinctions of birds. Philosophical Transactions: Biological Sciences, 344:35-40. 
Cohen, A.N. \& J.T. Carlton 1998. Accelerating invasion rate in a highly invaded estuary. Science 279:555-558.

Courchamp, F., J.L. Chapuis \& M. Pascal 2003. Mammal invaders on islands: impact, control and control impact. Biological Review 78:347-383.

Faaborg, J. 2003. Truly artificial nest studies. Conservation Biology 18:639-370.

Gates, J.E. \& L.W. Gysel 1978. Avian nest dispersion and fledging success in field forest ecotones. Ecology 59:871-883.

Hazler, K. 2004. Mayfield logistical regression: A practical approach for analysis of nest survival. Auk 121:707-716.

Ibarra, J.T., L. Fasola, D.W. Macdonald, R. Rozzi \& C. Bonacic 2009. Invasive American mink Mustela vison in wetlands of the Cape Horn Biosphere Reserve, Southern Chile: what are they eating. Oryx 43: 87-90.

Levine, J.M. \& C.M. D’Antonio 2003. Forecasting biological invasions with increasing international trade. Conservation Biology 17:322-326.

Levy, S. 2003. Getting the drop on Hawaiian invasives. BioScience, 53:694-699.

Lockwood, J.L., M.F. Hoopes \& M.P. Marchetti 2007. Invasion Ecology. Blackwell Publishing, Malden, MA. 304 pp.

Mack, R.N., D. Simberloff, M.Lonsdale, H. Evans, M. C lout \& F.A. Bazzaz 2000. Biotic invasions: causes, epidemiology, global consequences, and control. Ecological Applications, 10:689-710.

Mittermeier, R., C. Mittermeier, P. Robles-Gil, J. Pilgrim, G. Fonseca, J. Brooks \& J. Konstant 2002. Wilderness: Earth's Last Wild Places. Conservation International, Washington, DC. 573 pp.

Picman, J. 1988. Experimental study of predation on eggs of ground nesting birds: Effects of habitat and nest distribution. Condor, 90:124-131.
Roeman, G.W., C.J. Donlan \& F. Courchamp 2002. Golden eagles, feral pigs, and insular carnivores: How exotic species turn native predators into prey. Proceedings of the National Academy of the Sciences of the United States of America, 99:791-796.

Rozzi, R. \& M.F. Sherriffs 2003. The mink (Mustela vison Schreber, Carnivora: Mustelidae), a new alien mammal for Navarino Island. Anales Instituto Patagonia (Chile). 31:97-104.

Rozzi, R., F. Massardo, C.B. Anderson, A. Berghoefer, A. Mansilla, M. Mansilla \& J. Plana [eds.] 2006. Cape Horn Biosphere Reserve. Ediciones de la Universidad de Magallanes. Punta Arenas, Chile.

SAS Institute Inc. 2006. SAS 9.1.3. Help and documentation, Cary, North Carolina. Schuttler, E., J. Carcamo \& R. Rozzi 2008. Diet of the American mink Mustela vison and its potential impact on the native fauna of Navarino Island, Cape Horn Biosphere Reserve, Chile. Revista Chilena de Historia Natural, 81:585-598.

Simons, L.S. \& L.H. Simons 1990. Experimental studies of nest-destroying behavior by Cactus Wrens. Condor 92: 855-860.

Venegas, C. \& W. Sielfeld 1999. Catálogo de los vertebrados de la Región de Magallanes y Antártica Chilena. Ediciones de la Universidad de Magallanes, Punta Arenas, 122 pp.

Vitousek, P.M., C.M. D’Antonio, L.L. Loope \& R. Westerbrooks 1997. Biological invasions as global environmental change. American Scientist 84: 273-478.

Willson, M.F., J.L. Morrison, K.E. Sieving, T.L. de Santo, L. Santisteban \& I. Diaz 2001. Patterns of predation risk and survival of bird nests in a Chilean-agricultural landscape. Conservation Biology 15:447-456. 
